\title{
STRUKTUR KOMUNITAS PLANKTON PADA PERAIRAN YANG DITUMBUHI ECENG GONDOK SEBAGAI BIOINDIKATOR KUALITAS PERAIRAN DI DANAU RAWA PENING, SEMARANG
}

\author{
The plankton community structure in the waters covered by hyacinth as bioindicator the quality \\ of the waters of Lake Rawa Pening, Semarang

\section{Eritrina Ardining Tyas, Sahala Hutabarat*) dan Churun Ain} \\ Program Studi Manajemen Sumberdaya Perairan, Departemen Sumberdaya Akuatik \\ Fakultas Perikanan dan Ilmu Kelautan, Universitas Diponegoro \\ J1. Prof. Sudato, SH, Tembalang, Semarang, Jawa Tengah - 50275, Telp/Fax. +6224 7474698 \\ Email: eritrina.tyas@gmail.com
}

\begin{abstract}
ABSTRAK
Secara ekologis, Danau Rawa Pening kondisinya telah banyak mengalami perubahan yang diindikasikan oleh tidak terkontrolnya pertumbuhan tanaman akuatik seperti eceng gondok yang umumnya berkaitan dengan proses eutrofikasi. Tujuan dari penelitian untuk mengetahui kualitas perairan berdasarkan struktur komunitas plankton pada perairan yang ditumbuhi eceng gondok di Rawa Pening. Penelitian ini dilaksanakan pada bulan Oktober sampai November 2016. Metode yang digunakan adalah observatif dan pengambilan teknik sampling secara purposif dan uji laboratorium. Lokasi pengambilan sampel yaitu stasiun 1 merupakan daerah yang terdapat eceng gondok cukup tinggi (kerapatan tinggi dengan persentase berkisar $>70-100 \%$ ). Stasiun 2 merupakan daerah yang terdapat eceng gondok relatif sedang (kerapatan sedang dengan persentase berkisar 40-70\%). Stasiun 3 merupakan daerah yang terdapat eceng gondok relatif rendah (kerapatan rendah dengan persentase berkisar $<40 \%$ ) serta stasiun 4 merupakan daerah yang tidak terdapat eceng gondok. Hasil penelitian menunjukkan bahwa kelimpahan Fitoplankton berkisar 620-15690 Ind/L. Jenis Fitoplankton yang ditemukan terdiri dari 4 kelas yaitu Chlorophyceae, Bacillariophyceae, Cyanophyceae, Xanthophyceae. Kelimpahan Zooplankton berkisar 620-1608 Ind $/ \mathrm{m}^{3}$. Jenis Zooplankton yang ditemukan terdiri dari 5 kelas yaitu Zoomastigopora, Pytomastigopora, Euglenaphyceae, Rotiferaceae Ciliata, Crustacea. Kualitas perairan di Danau Rawa Pening masih pada batas-batas yang layak untuk kehidupan plankton.
\end{abstract}

Kata Kunci: Plankton, Eceng Gondok, Danau Rawa Pening.

\begin{abstract}
Ecologically, Lake Rawa Pening has been extensively amended condition indicated by the uncontrolled growth of aquatic plants such as water hyacinth which is generally related to the process of eutrophication. The goal of the research is to find out the quality of the waters of the plankton community structure based on waters covered by water hyacinth in the Lake Rawa Pening. This research was carried out in Oktober and November 2016. The method used is observatif field and taking of sampling in purposive and laboratory. The location of sampling is divided into four stations and each station is divided into two points. Station 1 is that there is water hyacinth is quite high (high density with a percentage ranging $<70$ 100\%). Station 2 is the area contained relatively water hyacinth are medium density (percentage of 40-70\%). Station 3 is the station contained water hyacinth is relatively low (low density with a percentage ranging from 40\%) as well as station 4 is there is no water hyacinth. The results showed that Phytoplankton abundance range 620-15690 Ind/L. Types of Phytoplankton found consists of 4 classes namely Chlorophyceae, Cyanophyceae, Bacillariophyceae, Xanthophyceae. The abundance of Zooplankton range 620-1608 Ind $/ \mathrm{m}^{3}$. Types of Zooplankton found consists of 5 classes, namely Zoomastigopora, Pytomastigopora, Euglenaphyceae, Rotiferaceae Ciliata, Crustacea. The quality of the waters of Lake Rawa Pening is still within the limits that are reasonable for the life of the plankton. Saprobik index (SI) of 2 and the value of Tropical Saprobik Index (TSI) of 1,33 this indicated that these waters are in a phase of Oligosaprobik toward $\beta$ mesosaprobik.
\end{abstract}

Keywords: Plankton, Eichhornia crassipes, Lake Rawa Pening.

*) Penulis penanggungjawab

${ }^{\circledR}$ Copyright by Management of Aquatic Resources (MAQUARES) 


\title{
1. PENDAHULUAN
}

Danau Rawa Pening mempunyai peranan sangat tinggi untuk masyarakat sekitar, yaitu irigasi pertanian, perikanan, pembangkit listrik tenaga air dan pariwisata. Namun, kondisinya telah banyak mengalami perubahan, yang diindikasikan oleh tidak terkontrolnya pertumbuhan tanaman akuatik yang umumnya berkaitan dengan proses eutrofikasi. Kurang lebih 120 ha wilayahnya tertutup oleh Eichornia crassipes, 20 - 50 ha oleh Hydrylla verticillata dan 100 ha oleh Salvinia cucculata (Lehmusluoto, et al., 1995 dalam Soeprobowati, 2010). Eutrofikasi yang terjadi di Rawa Pening menyebabkan pertumbuhan eceng gondok sangat pesat. Eutrofikasi merupakan proses pengayaan unsur hara atau produktivitas perairan karena pasokan bahan organik yang ditandai dengan tingginya konsentrasi total-P, total-N, dan klorofil-a, sehingga memacu pertumbuhan yang tidak terkontrol dari tumbuhan air (Reddy, 2005 dalam Marthana et al., 2014).

Struktur komunitas merupakan suatu kumpulan berbagai jenis mikroorganisme yang berinteraksi dalam suatu zonasi tertentu. Dinamika kelimpahan dan struktur komunitas fitoplankton terutama dipengaruhi oleh faktor fisika dan kimia, khususnya ketersediaan unsur hara (nutrien) serta kemampuan fitoplankton untuk memanfaatkannya (Muharram, 2006).

\section{MATERI DAN METODE PENELITIAN}

Materi penelitian ini adalah plankton (fitoplankton dan zooplankton) yang diambil dari perairan Danau Rawa Pening, Semarang.

\begin{abstract}
Alat dan Bahan
Alat yang digunakan untuk sampling lapangan plankton di Rawa Pening, Semarang yaitu menggunakan Plankton Net ukuran $25 \mu \mathrm{m}$, Plankton Net ukuran $150 \mu \mathrm{m}$, cool box, ember ukuran 100 liter, botol sampel $50 \mathrm{ml}$, line kuadran transek ukuran $5 \times 5 \mathrm{~m}$, kertas label, kamera, termometer air raksa dengan ketelitian $1^{\circ} \mathrm{C}$, secchi disk dengan ketelitian $1 \mathrm{~cm}$, GPS, bola arus, erlenmeyer, gelas ukur serta botol winkler, $\mathrm{pH}$ paper, Spektrofotometer. Alat yang digunakan dalam penelitian di laboratorium adalah Sedgwick-Rafter, cawan bogorov, mikroskop inverted (fase kontras) dengan ketelitian $4 \mathrm{x}$ 10, mikroskop binokuler, cover glass, pipet tetes, stempel pipette, buku identifikasi Sachlan (1982), Wirosaputro (1986), Vuuren et al. (2006), dan Bellinger dan Sigee (2010).
\end{abstract}

\section{Metode}

Pengambilan sampel air menggunakan wadah berupa ember yang telah ditandai 10 liter, penyaringan dilakukan menggunakan Plankton Net ukuran $25 \mu \mathrm{m}$ dilakukan sebanyak 10 kali pengambilan sehingga didapatkan volume tersaring 100 liter. Sampel air hasil penyaringan ditampung dalam bucket $(50 \mathrm{ml})$. Perhitungan jumlah plankton per liter, digunakan rumus APHA (1989), yaitu :

Keterangan :

$$
\mathrm{N}=\frac{\mathrm{T}}{\mathrm{L}} \times \frac{\mathrm{P}}{\mathrm{p}} \times \frac{\mathrm{V}}{\mathrm{V}} \times \frac{1}{\mathrm{~W}}
$$

$\mathrm{N} \quad=$ Jumlah fitoplankton per liter

$\mathrm{T}=$ Luas gelas penutup $\left(\mathrm{mm}^{2}\right)$

$\mathrm{L} \quad=$ Luas lapang pandang $\left(\mathrm{mm}^{2}\right)$

$\mathrm{P} \quad=$ Jumlah lapang pandang yang diamati

$\mathrm{V} \quad=$ Volume sampel fitoplankton yang tersaring $(\mathrm{ml})$

$\mathrm{v} \quad=$ Volume sampel fitoplankton di bawah gelas penutup $(\mathrm{ml})$

$\mathrm{w} \quad=$ Volume sampel fitoplankton yang disaring (liter).

Sebagian faktor dari rumus tersebut telah diketahui pada Sedgewick-Rafter, seperti : $\mathrm{T}=1000 \mathrm{~mm}^{2}, \mathrm{v}=1 \mathrm{ml}$, dan $\mathrm{L}=0,25 \mu \mathrm{mm}^{2}$ (dimisalkan satu lingkaran sama dengan luas pandang pada mikroskop dengan $\mathrm{r}=0,5 \mathrm{~mm}$ ), maka rumus tersebut menjadi:

$$
N=\frac{1000 m m 2}{0,25 \pi} \times \frac{P}{10} X \frac{V}{1 m l} X \frac{1}{w} \text { atau } N=\frac{100(P x V)}{0,25 \pi w}
$$

Pada zooplankton rumus yang digunakan dalam perhitungan kelimpahan $\left(\mathrm{m}^{3}\right)$, digunakan pada rumus Wardhana (2003), yaitu:

$$
\mathrm{N}(\mathrm{Ind} / \mathrm{m} 3)=(\mathrm{l} / \mathrm{p}) \mathrm{q}(1 / v)
$$

Keterangan :

$\mathrm{N}=$ jumlah plankton per $\mathrm{m}^{3}$ (ind $\left./ \mathrm{m}^{3}\right)$

$\mathrm{q}=$ jumlah plankton dalam bogorov 
$\mathrm{p}=$ volume sampel plankton dalam bogorov $(\mathrm{ml})$

$1=$ volume sampel plankton yang tersaring $(\mathrm{ml})$

$\mathrm{v}=$ volume air yang tersaring $\left(\mathrm{m}^{3}\right)$

\section{Indeks Keanekaragaman}

Perhitungan dilakukan dengan menggunakan Indeks Keanekaragaman Shanon - Wiener (Odum, 1993) yang dirumuskan sebagai berikut:

\section{Keterangan :}

$$
\mathrm{H}^{\prime}=-\sum_{i=0}^{S} P i \ln P i, \operatorname{dimana} \mathrm{Pi}=\mathrm{Ni} / \mathrm{N}
$$

$$
\begin{aligned}
& \mathrm{H}^{\prime}=\text { Indeks Keanekaragaman } \\
& \mathrm{Ni}=\text { Jumlah individu jenis ke-1 } \\
& \mathrm{N}=\text { Jumlah individu total }
\end{aligned}
$$

Kisaran indeks keanekaragaman:

$\mathrm{H}^{\prime}<2.30 \quad$ : Keanekaragaman rendah, kestabilan komunitas rendah

$2.30<\mathrm{H}^{\prime}<6.08$ : Keanekaragaman sedang, kestabilan komunitas sedang

$\mathrm{H}^{\prime}>6,08 \quad$ : Keanekaragaman tinggi, kestabilan komunitas tinggi.

\section{Indeks Keseragaman}

indeks keseragaman fitoplankton dan zooplankton menggunakan rumus sebagai berikut (Odum, 1993) :

Keterangan :

$$
E=\frac{H^{\prime}}{H^{\prime} \max }
$$

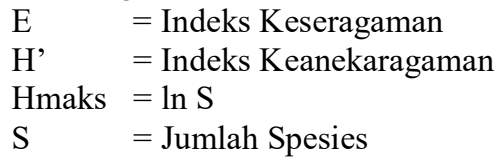

\section{Indeks Dominansi}

Perhitungan indeks dominansi untuk fitoplankton dan zooplankton menggunakan rumus indeks dominansi Simpson sebagai berikut (Odum, 1993) :

Dimana:

$$
\mathrm{D}=\Sigma\left(\mathrm{n}_{\mathrm{i}} / \mathrm{N}\right)^{2}
$$

$\mathrm{D}=$ indeks dominasi

$\mathrm{ni}=$ Jumlah individu spesies ke-i

$\mathrm{N}=$ Jumlah total individu.

\section{HASIL DAN PEMBAHASAN}

Hasil

Danau Rawa Pening terletak pada koordinat $07^{\circ} 4^{\prime} \mathrm{LS}-07^{\circ} 30^{\prime} \mathrm{LS}$ dan $110^{\circ} 24^{\prime} 46^{\prime \prime} \mathrm{BT}-110^{\circ} 49^{\prime} 06^{\prime \prime} \mathrm{BT}$ dan dikelilingi oleh tiga Gunung, yaitu Merbabu, Telomoyo, dan Ungaran. 
Struktur Komunitas Plankton pada Perairan yang Ditumbuhi Eceng Gondok sebagai Bioindikator Kualitas Perairan

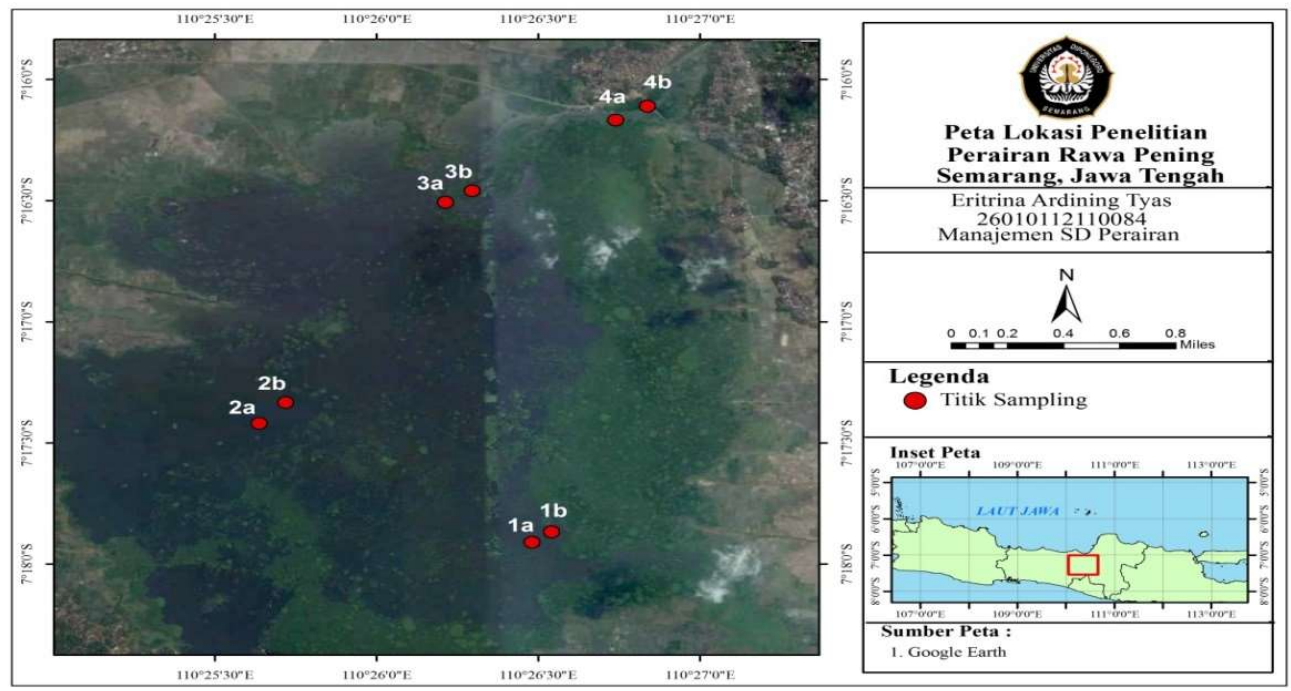

Gambar 1. Peta lokasi penelitian

\section{Jenis dan Kelimpahan Plankton}

Jenis fitoplankton yang ditemukan di Danau Rawa Pening terdiri dari 4 kelas yaitu Chlorophyceae, Bacillariophyceae, Cyanophyceae , Xanthophyceae. Kelimpahan fitoplankton rata-rata tertinggi sebesar 15690 Ind/l terdapat di stasiun 2 sdedangkan kelimpahan fitoplankton terendah 620 Ind/1 terdapat di stasiun 4.

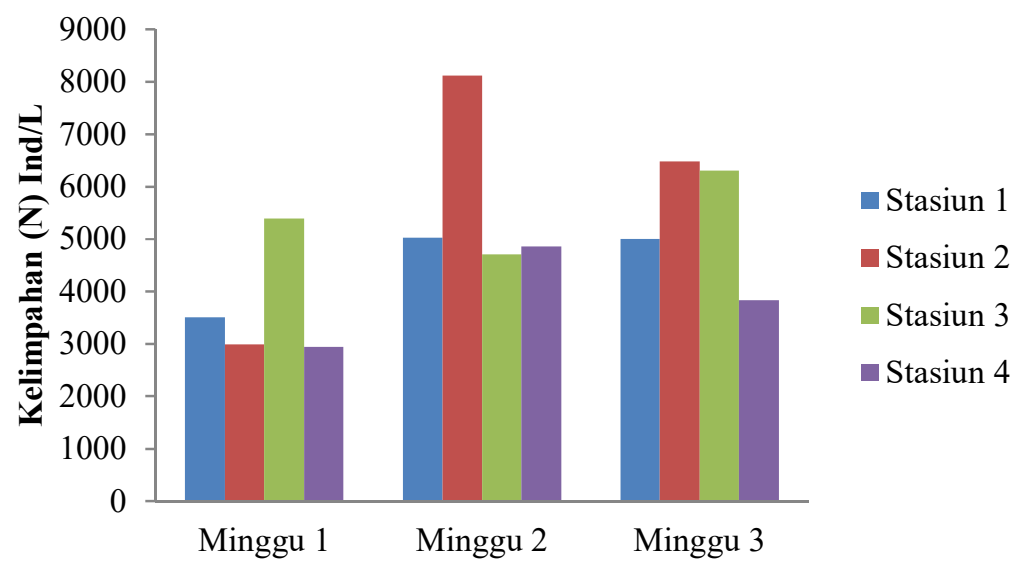

Gambar 2. Histogram jumlah kelimpahan Fitoplankton (Ind/l)

Jenis zooplankton yang ditemukan di Danau Rawa Pening Semarang terdiri dari 5 kelas yaitu kelas Zoomastigopora, Pytomastigopora, Euglenaphyceae, Rotiferaceae Ciliata, Crustacea. Kelimpahan Zooplankton rata-rata tertinggi sebesar $1608 \mathrm{Ind} / \mathrm{m}^{3}$ terdapat di stasiun 1 sedangkan kelimpahan Zooplankton rata-rata terendah sebesar 620 $\mathrm{Ind} / \mathrm{m}^{3}$ terdapat di stasiun 4 . 


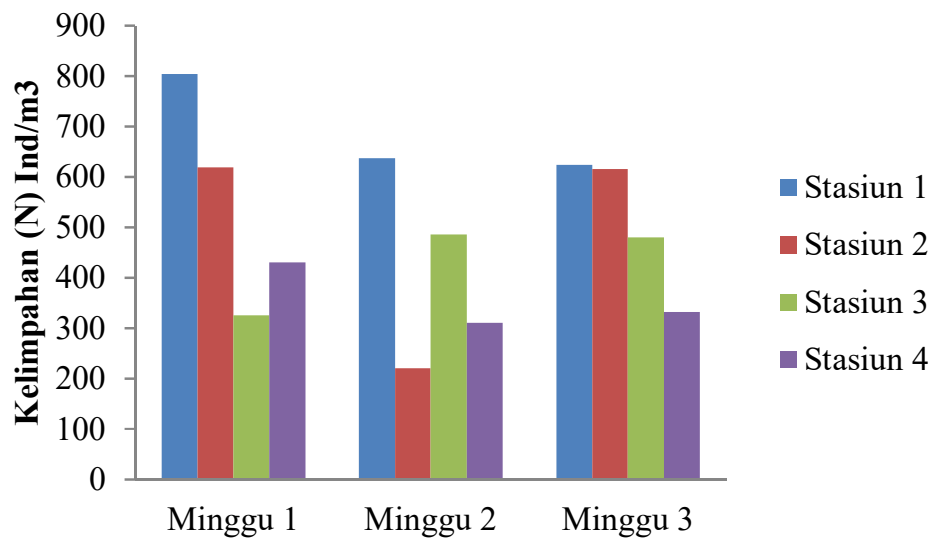

Gambar 3. Histogram jumlah kelimpahan Zooplankton (Ind $\left./ \mathrm{m}^{3}\right)$

Indeks Keanekaragaman (H'), Indeks Keseragaman (e), Indeks Dominansi (D).

Tabel 1. Nilai Indeks Keanekaragaman (H'), Indeks Keseragaman (e), dan Indeks Dominansi (D) Minggu ke-1

\begin{tabular}{|c|c|c|c|c|c|c|c|}
\hline \multirow{2}{*}{\multicolumn{2}{|c|}{ Stasiun }} & \multicolumn{3}{|c|}{ Fitoplankton } & \multicolumn{3}{|c|}{ Zooplankton } \\
\hline & & $\mathbf{H}^{\prime}$ & $\mathbf{e}$ & D & $\mathbf{H}^{\prime}$ & $\mathbf{e}$ & D \\
\hline \multirow{2}{*}{1} & $\mathrm{~A}$ & 2,445 & 0,863 & 0,112 & 2,125 & 0,828 & 0,136 \\
\hline & $\mathrm{B}$ & 2,270 & 0,860 & 0,109 & 2,189 & 0,853 & 0,122 \\
\hline \multirow{2}{*}{2} & A & 2,042 & 0,774 & 0,162 & 2,194 & 0,855 & 0,136 \\
\hline & $\mathrm{B}$ & 1,990 & 0,735 & 0,209 & 2,272 & 0,886 & 0,111 \\
\hline \multirow{2}{*}{3} & A & 1,932 & 0,713 & 0,188 & 1,994 & 0,777 & 0,130 \\
\hline & $\mathrm{B}$ & 2,050 & 1,053 & 0,161 & 1,936 & 0,755 & 0,169 \\
\hline \multirow{2}{*}{4} & A & 1,801 & 0,926 & 0,199 & 2,051 & 0,825 & 0,142 \\
\hline & $\mathrm{B}$ & 1,836 & 0,696 & 0,197 & 1,957 & 0,788 & 0,184 \\
\hline
\end{tabular}

Tabel 2. Nilai Indeks Keanekaragaman (H'), Indeks Keseragaman (e), dan Indeks Dominansi (D) Minggu ke-2

\begin{tabular}{cccccccc}
\hline \multirow{2}{*}{ Stasiun } & \multicolumn{3}{c}{ Fitoplankton } & \multicolumn{3}{c}{ Zooplankton } \\
& & H'$^{\prime}$ & e & D & H'$^{\prime}$ & e & D \\
\hline \multirow{2}{*}{1} & A & 2,048 & 0,756 & 0,189 & 1,715 & 0,881 & 0,198 \\
& B & 2,029 & 0,749 & 0,189 & 1,629 & 0,909 & 0,206 \\
2 & A & 1,810 & 0,668 & 0,229 & 1,707 & 0,953 & 0,187 \\
& B & 2,063 & 0,782 & 0,168 & 1,768 & 0,909 & 0,191 \\
3 & A & 2,427 & 0,857 & 0,092 & 1,551 & 0,797 & 0,277 \\
& B & 2,276 & 0,803 & 0,120 & 1,698 & 0,948 & 0,198 \\
4 & A & 1,948 & 0,719 & 0,159 & 1,769 & 0,909 & 0,183 \\
& B & 2,132 & 0,769 & 0,106 & 1,66 & 0,853 & 0,226 \\
\hline
\end{tabular}

Tabel 3. Nilai Indeks Keanekaragaman (H'), Indeks Keseragaman (e), dan Indeks Dominansi (D) Minggu ke-3

\begin{tabular}{cccccccc}
\hline \multirow{2}{*}{ Stasiun } & \multicolumn{3}{c}{ Fitoplankton } & \multicolumn{3}{c}{ Zooplankton } \\
& & $\mathbf{H}^{\prime}$ & e & D & $\mathbf{H}^{\prime}$ & e & D \\
\hline \multirow{2}{*}{1} & A & 2,177 & 0,785 & 0,113 & 1,253 & 1,141 & 0,323 \\
& B & 2,072 & 0,747 & 0,103 & 1,165 & 1,280 & 0,308 \\
2 & A & 1,935 & 0,715 & 0,143 & 1,353 & 0,976 & 0,281 \\
& B & 1,891 & 0,761 & 0,117 & 1,184 & 1,078 & 0,372 \\
3 & A & 1,993 & 0,703 & 0,152 & 1,297 & 1,181 & 0,298 \\
& B & 1,893 & 0,738 & 0,164 & 1,047 & 0,755 & 0,465 \\
4 & A & 1,833 & 0,715 & 0,144 & 1,261 & 0,784 & 0,357 \\
& B & 1,703 & 0,710 & 0,206 & 1,235 & 0,891 & 0,326 \\
\hline
\end{tabular}




\section{Kualitas Air}

Hasil pengukuran kualitas air di Danau Rawa Pening dapat dijelaskan sebagai berikut kecerahan berkisar 0,32-0,69 $\mathrm{m}$, kedalaman berkisar $0,74-1,87 \mathrm{~m}$, suhu air berkisar $29-32^{\circ} \mathrm{C}$, kecepatan arus berkisar $0,01-0,09 \mathrm{~m} / \mathrm{s}$, derajat keasaman $(\mathrm{pH})$ berkisar 5-6, Dissolved Oxygen (DO) berkisar 4 - 6,8 mg/L, nitrat berkisar 0,01 - 1,3 mg/L, fosfat berkisar 3,83 - 9,56 $\mathrm{mg} / \mathrm{L}$.

\section{Pembahasan \\ Fitoplankton}

Jenis fitoplankton yang paling sering muncul di lokasi penelitian selama pengamatan ialah Aulacoseira sp. dan Synedra sp. dari kelas Bacillariophyceae. Aulacoseira merupakan jenis diatom yang mengindikasikan suatu perairan cenderung eutrofik dengan $\mathrm{pH}$ asam (Zulfia dan Aisyah 2013).

jenis dan kelimpahan fitoplankton pada minggu pertama hingga minggu ketiga jumlah kelimpahan fitoplankton tertinggi sebesar $15690 \mathrm{Ind} / 1$ terdapat di stasiun 1 titik B yang merupakan daerah yang memiliki kerapatan eceng gondok yang tinggi. Kelimpahan fitoplankton cukup tinggi terjadi saat pagi hari dan kedalaman yang relatif rendah yaitu 1,07 $\mathrm{m}$ dan kecerahan $0,39 \mathrm{~m}$. Tingginya nilai kelimpahan jenis fitoplankton tersebut diduga karena adanya hubungan nutrient dan intensitas cahaya matahari yang cukup. Hal ini sesuai dengan Nontji (2006), fitoplankton mengandung klorofil yang mempunyai kemampuan berfotosintesis yakni menyerap energi matahari untuk mengubah bahan inorganik menjadi bahan organik. Menurut Hutabarat dan Evans, (1986) dalam Pohan (2011), Fitoplankton dalam melakukan fotosintesis membutuhkan cahaya matahari. Penyinaran cahaya matahari akan berkurang dengan makin tingginya kedalaman. Ini sebabnya fitoplankton sebagai produsen primer hanya didapat pada daerah atau kedalaman dimana sinar matahari dalam menembus perairan.

Jumlah kelimpahan terendah terdapat pada stasiun 4 titik A di minggu kedua sebesar 620 Ind/1. Stasiun tersebut merupakan daerah yang tidak terdapat eceng gondok. Jumlah kelimpahan lebih sedikit dibandingkan dengan jumlah kelimpahan yang terdapat di stasiun lainnya dikarenakan pengaruh kualitas perairan seperti oksigen terlarut (DO). Nilai DO pada stasiun 4 titik A yaitu $6 \mathrm{mg} / \mathrm{L}$. Menurut Effendi (2003), tingginya nilai oksigen terlarut (DO) karena terjadi proses fotosintesis dan menyebabkan kelimpahan fitoplankton rendah. Kandungan oksigen terlarut berfluktuasi secara harian (diurnal) dan musiman tergantung pada pencampuran (mixing) dan pergerakan (turbulence) masa air, aktifitas fotosintesis, respirasi dan limbah (effluent) yang masuk kedalam badan air.

\section{Zooplankton}

Jenis Zooplankton yang ditemukan di Danau Rawa Pening Semarang terdiri dari 5 kelas yaitu kelas Zoomastigopora, Pytomastigopora, Euglenaphyceae, Rotiferaceae Ciliata, Crustacea. Dilihat dari jumlah jenisnya didominansi oleh kelas Crustaceae. Tingginya jenis Crustaceae yang ditemukan dikarenakan jenis Crustaceae dapat toleran atau mampu beradaptasi terhadap perubahan lingkungan.

Hutabarat dan Evans (1986) mengatakan bahwa Crustaceae merupakan jenis plankton yang paling mudah dikenali dibandingkan dengan jenis plankton yang lain, baik dilihat dari segi bentuk larva maupun dewasanya, kadangkala juga banyak dijumpai dari kelompok meroplankton dari Crustaceae tingkat tinggi berupa larva.

Jumlah kelimpahan zooplankton tertinggi pada minggu pertama hingga minggu ketiga terdapat pada stasiun 1 yaitu sebesar $1608 \mathrm{Ind} / \mathrm{m}^{3}$ yang terdapat di stasiun 1. Stasiun tersebut merupakan perairan yang memiliki kerapatan eceng gondok yang tinggi. Jumlah kelimpahan zooplankton terendah sebesar $620 \mathrm{Ind} / \mathrm{m}^{3}$ terdapat pada minggu kedua di stasiun 4 titik A yang merupakan daerah yang tidak terdapat eceng gondok.

Kelimpahan plankton (fitoplankton dan zooplankton) suatu perairan erat kaitannya dengan kondisi lingkungan pada perairan tersebut. Organisme zooplankton yang ditemukan lebih sedikit dibandingkan organisme fitoplankton, oleh karena zooplankton diduga belum memanfaatkan fitoplankton secara optimal. Menurut Nontji (1993) dalam Indrayani et al. (2016), banyak zooplankton yang dapat melakukan gerakan naik turun secara berkala atau dikenal dengan migrasi vertikal. Pada malam hari zooplankton naik ke atas menuju permukaan sedangkan pada siang hari turun ke lapisan bawah. Menurut Basmi (2000), gerakan naik turun ini dapat menyebabkan perbedaan kelimpahan dan komposisi zooplankton antara lapisan dasar dan permukaan dari suatu perairan. Tingkat produksi dari zooplankton lebih rendah dibandingkan dengan fitoplankton sehingga puncak produksi zooplankton berada dibawah dan terjadi setelah puncak fitoplankton.

Kisaran kecerahan selama pengamatan di Danau Rawa Pening berkisar 0,32-0,69 m. Kecerahan tertinggi terjadi pada pagi hari, hal ini dikarenakan kedalaman yang dangkal sehingga intensitas cahaya matahari dapat masuk dengan optimal. Kecerahan suatu perairan ditentukan oleh adanya kandungan bahan organik yang ada di dalamnya. Semakin tinggi kandungan bahan organik menyebabkan nilai kecerahan semakin berkurang. Nilai kecerahan menunjukkan jumlah cahaya matahari masuk ke dalam perairan yang dipengaruhi oleh adanya padatan tersuspensi baik organik maupun anorganik (Boyd (1982) dalam Zulfia dan Aisyah, 2013).

Kisaran kedalaman selama pengamatan di Danau Rawa Pening berkisar 0,74-1,87 m. Kedalaman paling tinggi terdapat di stasiun 4 titik A pada minggu pertama. Sedangkan kedalaman paling rendah terdapat di stasiun 1 titik 
A.Kedalaman menentukan seberapa dalam cahaya matahari dapat menembus lapisan air. Cahaya matahari dalam suatu perairan sangat penting dalam membantu proses fotosintesis yang dilakukan oleh fitoplankton, dan melalui proses fotosintesis dapat meningkatkan kandungan oksigen terlarut (Welch, (1952) dalam Zulfia dan Aisyah, 2013).

Kisaran suhu air selama pengamatan di Danau Rawa Pening berkisar antara $29-32^{\circ} \mathrm{C}$. Tingginya nilai suhu tersebut diduga karena pengaruh cuaca dan waktu pengukuran yang dilakukan. Nilai suhu tersebut masih dalam kisaran suhu optimum bagi pertumbuhan biota di perairan yaitu antara 20 hingga $30^{\circ} \mathrm{C}$ serta merupakan suhu permukaan danau yang umum di wilayah tropis yang berkisar $28-29^{\circ} \mathrm{C}$ (Nybakken, 1988).

Kecepatan arus di Danau Rawa Pening berkisar antara 0,01-0,09 m/s. Kecepatan arus pada pagi hari cenderung tenang, hal ini dipengaruhi oleh cuaca atau kecepatan angin yang terjadi pada waktu pengambilan sampel.

Perairan Danau Rawa Pening mempunyai arus yang bervariasi dari waktu ke waktu bergantung dari musim. Pada saat pengambilan data, arus air sangat lambat bahkan cenderung tenang terutama pada bagian tepian danau. Tenangnya perairan danau ini disebabkan oleh beberapa hal yaitu wilayah perairan danau yang luas dengan satu outlet, dan saat pengambilan data, angin bertiup sangat lambat bahkan terkadang tidak ada angin sama sekali ( Nugroho et al., 2014).

Derajat Keasaman $(\mathrm{pH})$ selama pengamatan di Danau Rawa Pening berkisar antara 5-6. Kisaran nilai pH (derajat keasaman) Perairan Danau Rawa Pening bersifat alkalis/basa (Effendi, 2003). Menurut Boyd (1982) dalam Effendi (2003), secara umum bakteri tumbuh dengan baik pada $\mathrm{pH}$ netral dan alkalis (basa), karena yang diperlukan dalam proses dekomposisi bahan organik dan proses oksidasi adalah bakteri, maka nilai $\mathrm{pH}$ Perairan Rawa Pening mendukung adanya proses tersebut. Sebaliknya, proses fotosintesis akan mengalami laju penurunan jika $\mathrm{pH}$ terlalu asam atau terlalu basa.

Dissolved Oxygen atau oksigen terlarut di Danau Rawa Pening berkisar antara 4 - 6,8 mg/L. Pada perairan tawar, kadar oksigen terlarut berkisar antara $15 \mathrm{mg} / \mathrm{L}$ pada suhu $0^{\circ} \mathrm{C}$, dan $8 \mathrm{mg} / \mathrm{L}$ pada suhu $25^{\circ} \mathrm{C}$ (Effendi, 2003).

Nilai nitrat yang terkandung di Danau Rawa Pening berkisar antara $0,01-1,3 \mathrm{mg} / \mathrm{L}$. Kisaran nilai nitrat yang diperoleh masih berada di bawah standar nilai yang disyaratkan dalam PP No. 82 tahun 2001, yaitu 10 mg/L untuk penggunaan kelas I (air minum dan peruntukan lain dengan mutu yang disyaratkan sama) dan II (rekreasi air, budidaya, pertanaman) serta $20 \mathrm{mg} / \mathrm{L}$ untuk penggunaan kelas III (budidaya, pertanaman) dan IV (pertanaman dan peruntukan lain dengan mutu yang disyaratkan sama). Secara umum, konsentrasi nitrat pada perairan dengan kondisi baik (belum terkontaminasi polusi) berada pada kisaran rendah bahkan tidak terdeteksi hingga mencapai $10 \mathrm{mg} / \mathrm{L}$ (Wetzel, $2001 \mathrm{dalam}$ Muhtadi et al. 2015).

Nilai fosfat yang terkandung di Danau Rawa Pening berkisar antara 3,83 - 9,56 mg/l. Kandungan fosfat yang optimal bagi pertumbuhan fitoplankton berada pada kisaran 0,27-5,51 mg/L dan akan menjadi faktor pembatas apabila kurang dari 0,02 mg/L (Effendi, 2003).

\section{Indeks Keanekaragaman, Keseragaman, dan Dominansi Plankton}

Nilai indeks keanekaragaman fitoplankton pada minggu pertama hingga minggu ketiga menunjukkan bahwa perairan di Danau Rawa Pening memiliki keanekaragaman fitoplankton yang tergolong sedang karena nilai keanekaragaman berkisar 1,703-2,445. Nilai indeks keanekaragaman zooplankton pada minggu pertama hingga minggu ketiga berkisar antara 1,047-2,272. Hasil analisis keanekaragaman (H') fitoplankton dan zooplankton memperlihatkan bahwa secara umum perairan Danau Rawa Pening Semarang termasuk stabil moderat. Menurut Stirn (1981) apabila H' < 1, maka komunitas biota dinyatakan tidak stabil, apabila H' berkisar 1-3 maka stabilitas komunitas biota tersebut adalah moderat (sedang) dan apabila H' $>3$ berarti stabilitas komunitas biota berada dalam kondisi prima (stabil). Semakin besar nilai H' menunjukkan semakin beragamnya kehidupan di perairan tersebut, kondisi ini merupakan tempat hidup yang lebih baik. Kondisi di lokasi ini, mudah berubah dengan hanya mengalami pengaruh lingkungan yang relatif kecil. Berdasarkan berkelanjutan karena memiliki nilai keanekaragaman $\left(H^{\prime}>1\right)$.

Nilai keseragaman ftioplankton relatif tinggi berkisar antara 0,668-0,857. Nilai keseragaman zooplankton berkisar antar 0,755-1,280. Berdasarkan hasil bahwa jumlah individu setiap jenis tidak jauh berbeda. Menurut Basmi (2000), bahwa nilai indeks keseragaman mendekati 1 menandakan keseragaman antar spesies dapat dikatakan merata atau jumlah individu pada masing-masing spesies hampir sama.

Nilai dominansi fitoplankton tergolong sedang berkisar antara 0,103-0,229. Nilai dominansi zooplankton berkisar antara 0,111-0,465. Berdasarkan hasil bahwa terdapat individu tertentu yang mendominasi di perairain Danau Rawa Pening. Nilai indeks dominansi (D) fitoplankton dan zooplankton di perairan Danau Rawa Pening Semarang pada seluruh stasiun memperlihatkan nilai yang rendah yang berarti tidak terjadi dominasi spesies tertentu di perairan tersebut. Apabila nilai dominansi mendekati nilai 1 berarti di dalam komunitas terdapat spesies yang mendominansi spesies lainnya, sebaliknya apabila mendekati nilai 0 berarti di dalam struktur komunitas tidak terdapat spesies yang secara ekstrim mendominansi spesies lainnya (Basmi, 2000). 


\section{KESIMPULAN}

Kesimpulan yang didapat pada penelitian ini adalah sebagai berikut:

1. Jenis fitoplankton yang ditemukan pada perairan Danau Rawa Pening Semarang terdiri dari 4 kelas dan 18 genera, yaitu kelas Chlorophyceae (11 genera), Bacillariophyceae (3 genera), Cyanophyceae (2 genera), Xanthophyceae (2 genera). Sedangkan jenis Zooplankton yang ditemukan terdiri dari 5 kelas dan 13 genera, yaitu kelas Zoomastigopora (1 genera), Pytomastigopora (5 genera), Euglenaphyceae (3 genera), Rotiferaceae Ciliata (2 genera), Crustacea (3 genera).

2. Nilai indeks keanekaragaman fitoplankton berkisar 1,703-2,445. Nilai keseragaman berkisar antara 0,668-0,857 dan nilai dominasi berkisar antara 0,103-0, Nilai indeks keanekaragaman zooplankton berkisar antara 1,047-2,272. Nilai indeks keseragaman berkisar antara 0,755-1,280. Nilai indeks dominansi berkisar antara 0,111-0,465.

3. Kualitas perairan di Danau Rawa Pening Semarang masih pada batas-batas yang layak untuk kehidupan plankton.

\section{DAFTAR PUSTAKA}

Anggoro, S. 1988. Analisa Tropik-Sapronik (Trosap) Untuk Menilai Kelayakan Lokasi Budidaya Laut dalam : Workshop Budidaya Laut Perguruan Tinggi Se-Jawa Tengah. Laboratorium Pengembangan Wilayah Pantai. Universitas Diponegoro. Semarang. Hal. 66-90.

APHA (American Public Health Association). 1989. Standard Method for the Examinition of Water and Waste Water. American Public Health Association. Water Pollution Control Federation. Port City Press. Baltimore, Mariland. $1202 \mathrm{p}$.

Basmi. 2000. Planktonologi : Sebagai Indikator Pencemaran Perairan. Fakultas Perikanan dan Ilmu Kelautan. Institut Pertanian Bogor. Bogor.

Bellinger, E. G. dan D. C. Sigee. 2010. Freshwater Algae: Identification and Use as Bioindicators. John Wiley \& Sons Ltd, London.

Effendi, R. 2003. Telaah Kualitas Air. Penerbit Kanisius. Yogyakarta.

Hutabarat, S dan S.M. Evans. 1986. Kunci Identifikasi Zooplankton Daerah Tropik. UI Press. Jakarta.

Indrayani, N., Anggoro, S., \& Suryanto, A. (2014). Indeks Trofik-Saprobik Sebagai Indikator Kualitas Air di Bendung Kembang Kempis Wedung, Kabupaten Demak. Diponegoro Journal of Maquares Mana-gement of Aquatic Resources 3 (4), 161-168.

Marthana, W.S.M, Tri, R.S, dan Munifatul, I. 2014. Bioakumulasi Timbal (Pb) oleh Hydrilla verticillata L.f. Royle di Danau Rawapening, Ambarawa Semarang. Jurnal Sains dan Matematika, Vol. 22 (2): 52-59 (2014).

Muharram, N. 2006. Struktur Komunitas Perifiton dan Fitoplankton di Bagian Hulu Sungai Ciliwung, Jawa Barat. [Skripsi]. Departemen Sumberdaya Perairan. Fakultas Perikanan dan Ilmu Kelautan. Institut Pertanian Bogor.

Muhtadi, A., Yunasfi, F.F. Rais, N.A dan Ariska, D. 2015. Struktur komunitas biologi di Danau Pondok Lapan, Kabupaten Langkat Provinsi Sumatera Utara. Acta Aquatica 2:2. 83-89.

Nontji, A. 2006. Laut Nusantara. Penerbit Djambatan. Jakarta.

Nugroho, A.S., Shalihuddin D.T,. dan Boedhi H. 2014. Danau Rawa Pening sebagai Sumber belajar Ekologi. Pros Sem Nas Entrepreneurship. Hal:91-10.

Nybakken, J.W. 1988. Biologi Laut Suatu Pendekatan Ekologis. PT. Gramedia, Jakarta. 459 hal.

Odum, E.P. 1993. Dasar-dasar Ekologi. Edisi ketiga. Gadjah Mada University Press. Jogjakarta. H. 134-162.

Pohan, A.R. 2011. Keseragaman Plankton Di Perairan Rawa Desa Rantau Baru Bawah Kecamatan Pangkalan Kerinci Kabupaten Pelalawan Provinsi Riau. Skripsi Fakultas Perikanan dan Ilmu Kelautan Universitas Riau. Pekanbaru.

Sachlan, M. 1982. Planktonologi. Fakultas Perikanan dan Ilmu Kelautan Universitas Diponegoro, Semarang, 269 hlm. 
Soeprobowati, T.R dan Sri, W.A.S. 2010. Status Trofik Danau Rawapening Dan Solusi Pengelolaannya. Jurnal Sains \& Matematika, Volume 18 Nomor 4 Oktober 2010, ISSN 0854-0675.

Stirn, J. 1981. Manual Methods in Aquatic Environment Research. Part 8 Rome: Ecological Assesment of Pullution Effect, FAO.

Vuuren, S.J., Jonathan, T., Carin, G., Annelise, G. 2006. Easy Identification Of The Most Common Freshwater Alga. NorthWest University and Department of Water Affairs and Forestry.

Wardhana, W. 2003. Teknik Sampling Pengawetan dan Analisis Plankton. [Jurnal]. Disampaikan dalam Pelatihan Teknik Sampling dan Identifikasi Plankton. Balai Pengembangan dan Pengujian Mutu Perikanan. Jakarta.

Wirosaputro, S. 1986. Planktonologi Air Tawar. Jurusan Perikan Fakultas Pertanian UGM. Yogyakarta.

Zulfia, Naila dan Aisyah, 2013. Status Trofik Perairan Rawa Pening Ditinjau dari

Kandungan Unsur Hara (NO3 dan PO4) serta Klorofil-a. Vol. 5 (3) Desember 2013 : 189-199. 